\title{
Role of Killer Factors in the Inhibitory Activity of Bio-control Yeasts against Penicillium expansum and Aspergillus ochraceus
}

\author{
Ciro da Silva Portes, Andriélen Virke de Oliveira, Patrícia Simer, Alessandra Machado \\ Lunkes and Alexandre Rodrigo Coelho* \\ Universidade Tecnologica Federal do Paraná; Linha Santa Bárbara s/n; 85061-970; Francisco Beltrão - PR - \\ Brasil
}

\begin{abstract}
This work evaluated the antagonism of killer positive yeast strains (isolated from 11 samples of different frozen fruit pulps) against the strains of Penicillium expansum and Aspergillus ochraceus. Of the total 41 killer yeasts tested in YM agar, 19 showed antibiosis against $\mathrm{P}$. expansum and $\mathrm{A}$. ochraceus, with inhibition zone ranging from 10 to 18 $\mathrm{mm}$ and 10 to $19 \mathrm{~mm}$, respectively. In the following step, the extracellular activity of Kluyveromyces sp. FP4 $4_{13}$ was tested performing the assay in YM broth. The antifungal activity of Kluyveromyces sp. FP4 $4_{13}$ cell-free culture supernatant $\left(25^{\circ} \mathrm{C} / 96 \mathrm{~h}\right)$ was more effective against the conidia germination, showing inhibition rates of 93.33 and $86.44 \%$ for P. expansum and A. ochraceus, respectively. The micelial growth inhibition was 28.45 and $21.0 \%$, respectively. The antagonism showed by the selected yeasts could be used as a promising alternative tool to reduce and control the postharvest fungal spoilage of the fruits. However, further studies should be carried out in order to better elucidate the role of innocuous characters in antagonistic microorganisms, as well as the purification and characterization of new killer toxins.
\end{abstract}

Key words: Moulds, Killer yeasts, Biocontrol, Antibiosis

\section{INTRODUCTION}

Efforts have been made to improve the competitiveness in the area of agri-food system in Brazil. Brazilian fresh fruit exports had a growth of $13 \%$ during 2003/2007. Fruit productivity has been over 39 million tons, with the country ranking among the four largest fruit-producers worldwide, along with China, India and the USA (IBRAF 2010; FAO 2010). However, considerable losses occur in the commercial crops due to fruit susceptibility to infection by fungi, such as Penicillium expansum (Janisiewicz et al. 1998), Colletotrichum gloeosporioides (Rezende and
Fancelli 1997), Aspergillus ochraceus, Fusarium spp., and Alternaria spp. (Hussein and Brasel 2001; Nielsen et al. 2006). Thus, raw material productivity is dependent on fungicide application, leading to levels of undesirable chemical contaminants in the final product. Biological methods are viable alternatives to the traditional chemical methods, since no toxic residues remain on the fruit (Wilson and Wisniewski 1994). Biological products currently available, such as BIOSAVE II ® (Pseudomonas syringae), ASPIRE (Candida oleophila), and YIELD PLUS ${ }^{\circledR}$ (Cryptococcus albidus) have been used in the control of postharvest fruit diseases (Janisiewicz

*Author for correspondence: arcoelho@utfpr.edu.br 
and Korsten 2002; Wisniewski et al. 2007; Droby et al. 2002). This is in agreement with the use of yeasts in bio-control, based on the mycotoxigenic character of this group of microorganisms (Janisiewicz et al. 2003) and the presence of the killer factor in some strains. The killer factor is an extra-cellular peptide capable of inhibiting the growth of other microorganisms.

Biological control of the postharvest fruit diseases caused by mycotoxigenic moulds, combined with the investigation of bioactive compounds compatible with practical application, are necessary to ensure fruit quality and safety (Coelho et al. 2003). Thus, the aim of this work was to study the antagonism of killer positive yeasts against Penicillium expansum and Aspergillus ochraceus strains.

\section{MATERIALS AND METHODS}

\section{Moulds}

Single-spored $A$. ochraceus A152 and $P$. expansum n. 2 were isolated from naturallydecaying fruit. The culture was stored in Potato Dextrose Agar (PDA) at $4^{\circ} \mathrm{C}$ and cultivated on PDA slants at $21^{\circ} \mathrm{C}$ for $120 \mathrm{~h}$ before use. A spore suspension was prepared by inoculating the culture into $3.0 \mathrm{~mL}$ sterile distilled water containing $0.1 \%$ (v/v) Tween 80, and the cell number was adjusted to $1 \times 10^{5}$ spores $\mathrm{mL}^{-1}$ (Newbauer chamber).

\section{Antagonistic Agents}

Yeasts were isolated from the samples of 11 flavors of frozen fruit pulp by using Yeast Medium Agar-YM agar $(2.0 \%$ glucose, $0.5 \%$ yeast extract; $0.23 \% \mathrm{NaH}_{2} \mathrm{PO}_{4} ; 1.0 \% \mathrm{NaCl} ; 0.5 \%$ $\left(\mathrm{NH}_{4}\right)_{2} \mathrm{SO}_{4} ; 1.8 \%$ agar).The frozen fruit pulp used was obtained by a unique processing industry. The yeast isolates were maintained in GYMP Agar slant $(2.0 \%$ glucose, $1.0 \%$ malt extract, $0.5 \%$ yeast extract, $0.2 \% \quad \mathrm{NaHPO}_{4}$ and $1.8 \%$ agar) at $4{ }^{\circ} \mathrm{C}$. Yeast isolates showing potential antifungal activity, based on the antibiosis were identified by the commercial Kit RapidTM Yeast Plus System (Remel, Lenexa, USA). Yeasts were encoded and submitted to computerized identification system (Electronic Rapid Compendium-ERIC, Remel). For subsequent assay, the strains were activated in YM agar at $25^{\circ} \mathrm{C} / 48 \mathrm{~h}$.

\section{Killer Toxin Assay}

Isolated yeasts were submitted to killer toxin assay by using the killer sensitive reference strains of Candida glabrata NCYC 366, C. glabrata NCYC 388, C. albicans 12A, Pichia kluyveri CAY 15 and Saccharomyces cerevisiae NCYC 1006. The cell suspension of each reference strain $(100 \mu \mathrm{L}, 3 \mathrm{x}$ $10^{6}$ cells $\mathrm{mL}^{-1}$ ) was pour-plated in Methylene Blue Agar (MBA) following the method modified by Polonelli et al. (1983). A loop of the test strain reactivated in YM agar was inoculated (four testing strains/plate) onto the surface $(2 \mathrm{~mm}$ diameter) of previously prepared MBA, and the plate was incubated at $20^{\circ} \mathrm{C}$ for $72 \mathrm{~h}$. The killer positive strain was characterized as the colony with a clear surrounding zone, or the surrounding pour-plated reference culture was blue-stained (Walker et al. 1995). MBA was prepared in citrate-phosphate buffer, $\mathrm{pH} 4.5$ with the addition of $2.0 \%$ agar, $2.0 \%$ glucose, $1.0 \%$ peptone and $0.003 \%$ methylene blue, and autoclaved at $121^{\circ} \mathrm{C}$ for $15 \mathrm{~min}$. A killer strain of Saccharomyces cerevisiae NCYC-738 was used as positive control. The experiment was carried out in triplicate.

\section{Antifungal Assay in Solid Medium}

For the antifungal assay in solid medium, the inoculum of $10^{5}$ spores of A. ochraceus and $P$. expansum was pour-plated in $25 \mathrm{~mL} \mathrm{YM}$ agar. After solidification, an $8 \mathrm{~mm}$ diameter well was made in the center of the plate, followed by inoculation of $100 \mu \mathrm{L}$ yeast cultivate (YM broth at $25^{\circ} \mathrm{C} / 48 \mathrm{~h}$ ), corresponding to $3.0 \times 10^{6}$ cells $\mathrm{mL}^{-1}$. Plates were incubated at $25^{\circ} \mathrm{C}$ and the inhibition zone was measured after 5 days.

The antifungal assay in solid medium was used for screening the yeasts with potential activity against the fungal strains. This method allowed observing two types of inhibition, i.e., competition for the nutrients, identified by yeast growth pumping through the edge of the well and/or extra-cellular compound production by antibiosis, characterized by the inhibition zone with no growth of spoilage mould (Coelho et al. 2007).

\section{Antifungal Assay in Broth Culture}

The antifungal assay in broth culture was essentially based on the methods described by Janisiewicz et al. (2000) and Chen et al. (1999), followed by the microscopic analysis. The yeast isolates showing potential activity against the fungal tests in the solid medium assay were submitted to antifungal assay in broth culture. Kluyveromyces sp. $\mathrm{FP}_{13}$ was activated in $\mathrm{YM}$ 
broth at $25^{\circ} \mathrm{C}$ for $24 \mathrm{~h}(150 \mathrm{rpm})$, and $100 \mu \mathrm{L}$ of cell suspension $\left(3.0 \times 10^{6}\right.$ cells $)$ were inoculated in five Erlenmeyer flasks with $50 \mathrm{~mL}$ of YM broth. After $24,48,72,96$, and $120 \mathrm{~h}$ incubation at $25^{\circ} \mathrm{C}$ under static condition, one yeast culture flask was centrifuged $(6,500 \mathrm{x} \mathrm{g}$ for $15 \mathrm{~min})$ and filter sterilized $(0.20 \mu \mathrm{m}$, Millipore Corporation, Bedford, MA, USA). An aliquot (1.0 mL) of the sterilized supernatant was added to $1 \mathrm{~mL}$ of YM broth (120 x $13 \mathrm{~mm}$ tube), and inoculated with fungal tests $\left(10^{5}\right.$ spores $)$. Tubes were incubated at $25^{\circ} \mathrm{C}$ for $12 \mathrm{~h}$, and conidial germination percentage and fungal growth were determined by an optical microscope. Negative control was performed in the tubes without yeast culture supernatant $\left(10^{5}\right.$ spores of fungal test in $1.0 \mathrm{~mL}$ sterile water plus $1 \mathrm{~mL}$ YM broth). The conidial germination percentage in the culture with supernatant $(\mathrm{X})$ was calculated as:

\section{$X=\underline{100 \times \text { mean conidia germination in the supernatant }}$ mean conidial germination in the control}

The inhibition percentage of conidial germination was calculated as $100 \%$ inhibition - X.

The hyphal length in the culture with the supernatant (Y) was calculated as:

$\mathrm{Y}=\underline{100 \times \text { mean hyphal length in the supernatant }}$ mean hyphal length in the control

The inhibition percentage of hyphal growth was calculated as $100 \%$ inhibition - Y.

The experiment was carried out in three replications (at three different time) over eight months; for each replication, the mean hyphal lengths were obtained by measuring 40 random hyphae in $\mu \mathrm{m}$. Conidial germination data were based on two counts of 100 conidia per repetition (Chen et al. 1999). The data from three replications were analyzed by comparing the mean values obtained from 120 data for hyphal length and 6 data for conidial percentage.

\section{Statistical Analysis}

The 120 data for hyphal lengths and the six data for conidia germination percentage, obtained from three replications, were evaluated by Tukey test ( $p$ $<0.05)$ using the Anova/Manova program (Statistica version 7.0, Inc. Tulsa ,OK, USA, 2005).

\section{RESULTS AND DISCUSSION}

\section{Isolation and Identification of Killer Yeast}

Forty-one yeasts were isolated from 11 samples of different frozen fruit pulps, as shown in Table 1. Table 2 shows the killer positive yeast isolates against the standard yeast strains. Of the total yeasts tested, $31(75.6 \%)$ were positive for the killer character. Of these, 24 yeasts $(77.4 \%)$ showed killer activity against more than one standard sensitive strain, with six being against two standard sensitive strains; 13 against three; four against four; and one against all standard sensitive strains. Seven yeast isolates showed killer factor against only one standard sensitive strain (Table 2).

Table 1 - Yeast strains isolated from frozen fruit pulps.

\begin{tabular}{ll}
\hline Samples of frozen fruit pulps & Yeast strains code* \\
\hline Papaya & $\mathrm{FP} 1_{1}, \mathrm{FP} 1_{2}, \mathrm{FP} 1_{3}, \mathrm{FP} 1_{4}, \mathrm{FP} 1_{5}$. \\
Guava & $\mathrm{FP} 2_{1}, \mathrm{FP} 2_{2}, \mathrm{FP} 2_{3}, \mathrm{FP} 2_{5}, \mathrm{FP} 2_{6}$. \\
Raspberry & $\mathrm{FP} 3_{3}, \mathrm{FP} 3_{4}, \mathrm{FP} 3_{5}$. \\
Grape & $\mathrm{FP} 4_{1}, \mathrm{FP} 4_{2}, \mathrm{FP} 4_{3}, \mathrm{FP} 4_{6}, \mathrm{FP} 4_{8}, \mathrm{FP} 4_{11}, \mathrm{FP} 4_{13}$. \\
Pineapple & $\mathrm{FP} 8_{1}, \mathrm{FP} 8_{4}, \mathrm{FP} 8_{5}, \mathrm{FP} 8_{8}$. \\
Orange & $\mathrm{FP} 9_{1}, \mathrm{FP} 9_{2}, \mathrm{FP} 9_{3}$. \\
Passion fruit & $\mathrm{FP} 10_{2}$. \\
Peach & $\mathrm{FP} 12_{1}$. \\
Mango & $\mathrm{FP} 13_{1}, \mathrm{FP} 13_{3}, \mathrm{FP} 13_{4}, \mathrm{FP} 13_{5}$. \\
Açai & $\mathrm{FP} 14_{2}, \mathrm{FP} 14_{3}, \mathrm{FP} 14_{4}$. \\
Acerola & $\mathrm{FP} 16_{2}, \mathrm{FP} 16_{4}, \mathrm{FP} 16_{6}, \mathrm{FP} 16_{7}, \mathrm{FP} 16_{8}$. \\
\hline FPn $\cdot \mathrm{FP}=$ fruit pulp; $n=$ sample number $;=$ number of culture
\end{tabular}

* $\mathrm{FPn}_{\mathrm{n}}: \mathrm{FP}=$ fruit pulp; $\mathrm{n}=$ sample number; ${ }_{\mathrm{n}}=$ number of culture 
Table 2 - Killer character of yeast isolates against standard sensitive strains.

\begin{tabular}{|c|c|}
\hline Standard sensitive yeast strains & Killer positive yeast strains \\
\hline Candida glabrata NCYC 366 & $\mathrm{FP} 2_{1}, \mathrm{FP} 4_{2}$ \\
\hline Candida glabrata NCYC 388 & $\begin{array}{l}\mathrm{FP} 2_{1}, \mathrm{FP} 2_{3}, \mathrm{FP} 2_{5}, \mathrm{FP} 3_{3}, \mathrm{FP} 3_{4}, \mathrm{FP} 3_{5}, \mathrm{FP} 4_{1}, \mathrm{FP} 4_{2}, \mathrm{FP} 4_{13}, \mathrm{FP} 12_{1}, \mathrm{FP} 13_{1}, \mathrm{FP} 13_{3}, \\
\mathrm{FP} 13_{5}, \mathrm{FP} 16_{4}\end{array}$ \\
\hline Candida albicans $12 \mathrm{~A}$ & $\begin{array}{l}\mathrm{FP} 1_{1}, \mathrm{FP} 1_{3}, \mathrm{FP} 2_{3}, \mathrm{FP} 2_{5}, \mathrm{FP} 2_{6}, \mathrm{FP} 3_{4}, \mathrm{FP} 3_{5}, \mathrm{FP} 4_{1}, \mathrm{FP} 4_{2}, \mathrm{FP} 4_{3}, \mathrm{FP} 4_{6}, \mathrm{FP} 4_{8}, \\
\mathrm{FP} 4_{11}, \mathrm{FP} 4_{13}, \mathrm{FP} 8_{1}, \mathrm{FP} 9_{3}, \mathrm{FP} 10_{2}, \mathrm{FP} 13_{1}, \mathrm{FP} 13_{3}, \mathrm{FP} 13_{5}, \mathrm{FP} 14_{2}, \mathrm{FP} 16_{4}, \mathrm{FP} 16_{6} .\end{array}$ \\
\hline yveri CAY-15 & $\begin{array}{l}\mathrm{FP}_{3}, \mathrm{FP}_{3}, \mathrm{FP} 2_{5}, \mathrm{FP} 2_{6}, \mathrm{FP} 3_{3}, \mathrm{FP} 3_{4}, \mathrm{FP} 3_{5}, \mathrm{FP} 4_{1}, \mathrm{FP} 4_{2}, \mathrm{FP} 4_{3}, \mathrm{FP} 4_{6}, \mathrm{FP} 4_{8}, \\
\mathrm{FP}_{4}, \mathrm{FP}_{1}, \mathrm{FP} 8_{4}, \mathrm{FP} 9_{2}, \mathrm{FP} 12_{1}, \mathrm{FP} 13_{1}, \mathrm{FP} 13_{3}, \mathrm{FP} 13_{5}, \mathrm{FP} 16_{4}, \mathrm{FP} 16_{6} .\end{array}$ \\
\hline Saccharomyces cerevisiae NCYC-1006 & $\begin{array}{l}\mathrm{FP} 1_{1}, \mathrm{FP} 1_{2}, \mathrm{FP} 1_{3}, \mathrm{FP} 1_{4}, \mathrm{FP} 3_{3}, \mathrm{FP} 3_{5}, \mathrm{FP} 4_{1}, \mathrm{FP} 4_{2}, \mathrm{FP} 4_{3}, \mathrm{FP} 4_{6}, \mathrm{FP} 4_{8}, \mathrm{FP} 4_{11}, \\
\mathrm{FP} 4_{13}, \mathrm{FP} 8_{1}, \mathrm{FP} 2_{1}, \mathrm{FP} 14_{2}, \mathrm{FP} 14_{3}, \mathrm{FP} 16_{4} .\end{array}$ \\
\hline
\end{tabular}

Figure 1 showed the killer positive strains against the reference strain S. cerevisiae NCYC 1006, which showed a clear surrounding zone on methylene blue agar surface. This work presented more results than the study conducted by Coelho et al. (2011) using 44 yeast strains isolated from different natural sources in northern Parana, which showed only $29.55 \%$ with positive outcome for the killer factor. However, Oliveira et al. (2011) obtained $100 \%$ positivity to the killer factor in 24 yeasts isolated from the commercial and organic strawberry.

The yeast isolates that showed killer factor against more than one sensitive strain suggested that the killer toxin produced could have a large spectrum of action. On the other hand, yeasts could produce more than one killer toxin, such as killer toxins $\mathrm{K} 1$, $\mathrm{K} 2$, and $\mathrm{K} 28$, produced by $S$. cerevisiae (Schmitt and Breinig 2002). Also, the yeast strains $\mathrm{FP} 2_{1}$ and $\mathrm{FP}_{2}$ showed killer factor against C. glabrata NCYC 366 and C. glabrata NCYC
388, indicating the possible production of a unique antagonistic substance (Poloneli et al. 1983). Similar results were also found by Coelho et al. (2011) and Oliveira et al. (2011) against the same standard sensitive strains.

Yeast strains $\mathrm{FP} 2_{3}, \mathrm{FP} 4_{1}$, and $\mathrm{FP} 4_{13}$ were identified by using the commercial kit RapidTM Yeast Plus System (Remel, Lenexa, USA). According to the results, starin $\mathrm{FP}_{3}$ was $S$. cerevisiae and $\mathrm{FP} 4_{1}$ and $\mathrm{FP}_{13}$ were Kluyveromyces sp., whose probabilities were >99.9, 99.88 and $99.88 \%$, respectively.

The results of this work suggested that the killer phenomenon showed by $S$. cerevisiae $\mathrm{FP}_{2}$ and Kluyveromyces sp. strains $\mathrm{FP} 4_{1}$ and $\mathrm{FP} 4_{13}$ could be similar to that reported by other works, such as the production of K1, K2, and K28 killer toxins by $S$. cerevisiae and killer toxins from $K$. lactis and $K$. wickerhamii (Philliskirk and Young 1975; Golubev 1998; Schmitt and Breinig 2002; Comitini et al. 2004).

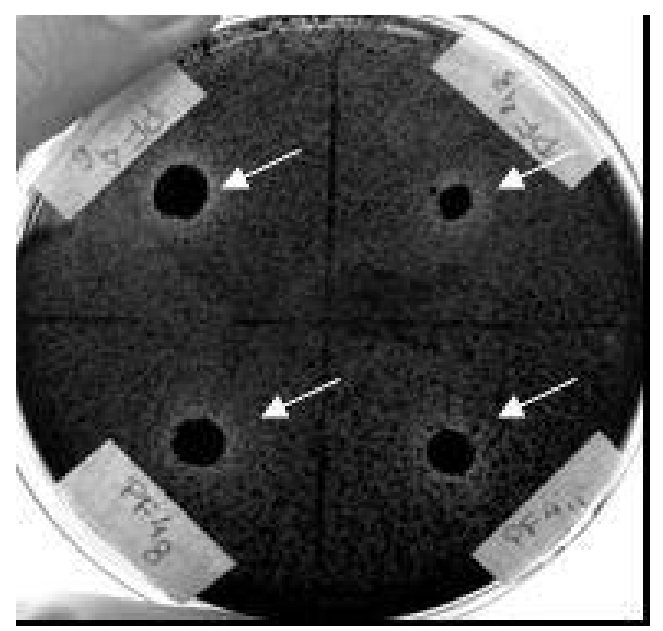

Figure 1 - Killer positive yeast strains on Sabouraud agar added with $0.003 \%$ methylene blue (Polonelli et al. 1983) containing Saccharomyces cerevisiae NCYC 1006 as a sensitive reference strain, incubated at $25^{\circ} \mathrm{C}$ for $72 \mathrm{~h}$. 


\section{Antifungal Assay}

Yeasts were submitted to antifungal assay in solid medium against $P$. expansum n. 2 and $A$. ochraceus A152 as a screening method. Of the total 41 yeasts tested, $24 \quad(58.5 \%)$ showed antifungal activity against $P$. expansum n. 2, out of which 19 (79.2\%) showed antagonism, based exclusively on antibiosis (clear inhibition zone due to production of extracellular substances), with inhibition zone ranging from 10 to $18 \mathrm{~mm}$. Three yeasts (12.5\%) showed antagonism based on nutrient competition (evidenced as cellular mass growth on the surface of the YM agar), and four (16.7\%) based on synergism (nutrient competition and antibiosis), between 48 and $120 \mathrm{~h}$ incubation at $25^{\circ} \mathrm{C}$ (Table 3). Geng et al. (2011) reported significant antagonistic effect by $K$. marxianus 1.0 x $10^{8} \mathrm{CFU} / \mathrm{mL}$ against $P$. digitatum, showing $95.6 \%$ inhibition of spore germination.

Table 3 - Antifungal activity in YM agar of yeasts viable cells against to Penicillium expansum n. 2 and Aspergillus ochraceus A152.

\begin{tabular}{|c|c|c|c|c|c|c|}
\hline \multirow{3}{*}{ Yeast code } & \multicolumn{6}{|c|}{ Inhibition zone (mm) } \\
\hline & \multicolumn{3}{|c|}{ P. expansum n. 2} & \multicolumn{3}{|c|}{ A. ochraceus A152 } \\
\hline & $\mathrm{NC}$ & $\mathbf{A}$ & $\mathrm{NC} / \mathrm{A}$ & $\mathrm{NC}$ & $\mathbf{A}$ & $\mathrm{NC} / \mathrm{A}$ \\
\hline $\mathrm{FP} 1_{1}$ & & 11.0 & & & 14.0 & \\
\hline $\mathrm{FP} 1_{3}$ & & 10.0 & & & 12.0 & \\
\hline $\mathrm{FP}_{4}$ & & 16.0 & & & 11.0 & \\
\hline $\mathrm{FP} 2_{1}$ & & 14.0 & & & 12.0 & \\
\hline $\mathrm{FP} 2_{2}$ & & & $10.0 / 16.0$ & & 16.0 & \\
\hline $\mathrm{FP}_{2}$ & & 12.0 & & & 14.0 & \\
\hline $\mathrm{FP} 2_{5}$ & & 10.0 & & & 12.0 & \\
\hline $\mathrm{FP} 2_{6}$ & & 14.0 & & & 18.0 & \\
\hline $\mathrm{FP} 4_{1}$ & & 13.0 & & & 13.0 & \\
\hline $\mathrm{FP} 4_{3}$ & & & & & & $10.0 / 16.0$ \\
\hline $\mathrm{FP} 4_{6}$ & & & & & 14.0 & \\
\hline $\mathrm{FP} 4_{8}$ & & & & & & $9.0 / 16.0$ \\
\hline $\mathrm{FP} 4_{11}$ & & & & & & $9.0 / 17.0$ \\
\hline $\mathrm{FP}_{13}$ & & 12.0 & & & 19.0 & \\
\hline $\mathrm{FP}_{4}$ & & 14.0 & & & 14.0 & \\
\hline $\mathrm{FP}_{8}$ & & & $10.0 / 17.0$ & & & $10.0 / 16.0$ \\
\hline $\mathrm{FP} 9_{1}$ & & 10.0 & & & 19.0 & \\
\hline $\mathrm{FP}_{2}$ & 13.0 & & & & & \\
\hline $\mathrm{FP}_{3}$ & & 14.0 & & & 16.0 & \\
\hline $\mathrm{FP} 10_{2}$ & & 12.0 & & & 11.0 & \\
\hline FP13 & & 11.0 & & & 11.0 & \\
\hline $\mathrm{FP} 13_{3}$ & & 12.0 & & & 12.0 & \\
\hline $\mathrm{FP} 13_{5}$ & & 15.0 & & & & \\
\hline $\mathrm{FP} 14_{2}$ & 10.0 & & & 13.0 & & \\
\hline $\mathrm{FP} 14_{3}$ & & & $12.0 / 24.0$ & & & $13.0 / 16.0$ \\
\hline $\mathrm{FP} 14_{4}$ & & 17.0 & & & & \\
\hline FP16 4 & 11.0 & & & & & \\
\hline FP16 6 & & 16.0 & & & 12.0 & \\
\hline $\mathrm{FP}_{16}$ & & 18.0 & & & & \\
\hline FP16 8 & & & $11.0 / 19.0$ & & 10.0 & \\
\hline
\end{tabular}

$\mathrm{NC}=$ Nutrient Competition; $\mathrm{A}=$ Antibiosis .

The antagonism focused in this study was shown by the antibiosis, i.e., the production of extracellular substances that inhibited the growth of other microorganisms. Thus, yeast strains $\mathrm{FP}_{3}$,
$\mathrm{FP} 2_{6}, \mathrm{FP} 4_{1}, \mathrm{FP} 4_{13}, \mathrm{FP}_{4}, \mathrm{FP} 9_{3}, \mathrm{FP} 10_{2}, \mathrm{FP} 13_{3}$, $\mathrm{FP} 13_{5}, \mathrm{FP}_{4} 4_{4}, \mathrm{FP}_{16}$ and $\mathrm{FP}_{6} 6_{7}$ showed greater antagonism against $P$. expansum n. 2, with inhibition zone ranging from 12 to $18 \mathrm{~mm}$ (Table 
3). Coelho et al. (2011) found positive results for antagonism in $20(45.5 \%)$ out of the 44 yeasts tested against $P$. expansum, with 15 being for nutrient competition and 5 with indications of antibiosis, with inhibition diameters ranging from 10 to $31 \mathrm{~mm}$ and 13 to $17 \mathrm{~mm}$, respectively.

As for antagonism against Aspergillus ochraceus A152, out of the 41 yeasts tested, $25(61.0 \%)$ showed antagonism, with $19 \quad(76.0 \%)$ being exclusively by the antibiosis, with inhibition zone ranging from 10 to $19 \mathrm{~mm}$; one yeast isolate $(4.0 \%)$ inhibited the mould by nutrient competition; and five yeasts (20\%) showed synergistic effect against A. ochraceus A152. Yeast strains $\mathrm{FP} 1_{1}, \mathrm{FP} 2_{2}, \mathrm{FP} 2_{3}, \mathrm{FP} 2_{6}, \mathrm{FP}_{1}, \mathrm{FP} 4_{6}$, $\mathrm{FP}_{13}, \quad \mathrm{FP}_{4}, \quad \mathrm{FP} 9_{1}$ and $\mathrm{FP}_{3}$ showed greater antagonism based on the antibiosis, with inhibition zone ranging from 13 to $19 \mathrm{~mm}$ (Table 3). However, some yeasts that were antagonistic by the antibiosis against one, or both spoilage mould did not show positivity to the killer factor (strains $\mathrm{FP}_{2}, \mathrm{FP}_{8}, \mathrm{FP}_{1}, \mathrm{FP}_{4}, \mathrm{FP}_{4} 6_{7}$ and $\mathrm{FP} 16_{8}$ ). This could be explained by the production of other extra-cellular substances, such as the detection of exoquitinase [N-acetyl-D-glucosaminidase (Nagase)] and $\beta-1-3$-glucanase produced by Aureobasidium pullulans (LS-30) against the development of $B$. cinerea, $P$. expansum, Rhizopus stolonifer and $A$. niger conducted in vitro and in apple wounds (Castoria et al. 2001). Wickerhamomyces anomalus, grown on acidified medium, showed mycotoxigenic activity against $P$. digitatum resulting from $\beta$-glucanase activity (Platania et al. 2012).

In general, $S$. cerevisiae strain $\quad \mathrm{FP} 2_{3}$ and Kluyveromyces sp. strains $\mathrm{FP}_{1}$ and $\mathrm{FP} 4_{13}$ showed satisfactory results against the development of the spoilage mould tested. According to the results, Kluyveromyces sp. $\mathrm{FP}_{13}$ was selected for the subsequent tests in antifungal assay in YM Broth. The antifungal assay in YM Broth has been proved to be a more sensitive test than the solid medium, since it is a quantification method that allows counting conidial germination and measuring fungal hyphal length (Janisiewicz et al. 2000). For this stage, Kluyveromyces sp. $\mathrm{FP} 4_{13}$ was used since it presented a good performance in the antifungal assay in YM agar, as shown in Table 3. Tests were conducted with cell-free culture supernatant from the yeast cultivation with a growing control of the tested moulds. The antifungal activity was more effective against the conidial germination than the inhibition of hyphal growth for $P$. expansum and A. ochraceus (Table 4, Fig. 2).

Table 4 - Antifungal activity in YM Broth of cell-free culture supernatant from Kluyveromyces sp. FP413 . against Penicillium expansum n. 2 and Aspergillus ochraceus A152.

\begin{tabular}{|c|c|c|c|c|}
\hline \multirow{3}{*}{$\begin{array}{l}\text { Incubation } \\
\text { Period (h) }\end{array}$} & \multicolumn{4}{|c|}{ P. expansum n. 2 growth } \\
\hline & \multicolumn{2}{|c|}{ Hyphal length $(\mu \mathrm{m})$} & \multicolumn{2}{|c|}{ Conidia germination (\%) } \\
\hline & Control & Yeast supernatant & Control & Yeast supernatant \\
\hline 24 & $40.10 \pm 10.01^{\mathrm{aA}}$ & $39.42 \pm 20.17^{\mathrm{bcA}}$ & $65.001 .41^{\mathrm{aB}}$ & $56.00 \pm 2.61^{\mathrm{dA}}$ \\
\hline 48 & $36.67 \pm 10.93^{\mathrm{aA}}$ & $38.05 \pm 11.40^{\mathrm{bcA}}$ & $60.00 \pm 1.41^{\mathrm{bB}}$ & $30.00 \pm 0.89^{\mathrm{cA}}$ \\
\hline 72 & $34.96 \pm 8.75^{\mathrm{aB}}$ & $31.19 \pm 6.20^{\mathrm{abA}}$ & $62.00 \pm 2.80^{\mathrm{bB}}$ & $29.00 \pm 0.63^{\mathrm{cA}}$ \\
\hline 96 & $39.76 \pm 15.15^{\mathrm{aB}}$ & $28.45 \pm 3.66^{\mathrm{aA}}$ & $60.00 \pm 0.63^{\mathrm{bB}}$ & $4.00 \pm 1.26^{\mathrm{aA}}$ \\
\hline 120 & $53.47 \pm 13.82^{\mathrm{bB}}$ & $40.79 \pm 6.01^{\mathrm{cA}}$ & $77.00 \pm 1.79^{\mathrm{cB}}$ & $18.00 \pm 0.89^{\mathrm{bA}}$ \\
\hline
\end{tabular}

A. ochraceus A152 growth*

\begin{tabular}{|c|c|c|c|c|}
\hline & \multicolumn{2}{|c|}{ Hyphal length $(\mu \mathrm{m})$} & \multicolumn{2}{|c|}{ Conidia germination (\%) } \\
\hline & Control & Yeast supernatant & Control & Yeast supernatant \\
\hline 24 & $30.51 \pm 5.80^{b A^{*}}$ & $31.02 \pm 6.94^{\mathrm{cA}}$ & $79.00 \pm 0.89^{\mathrm{cB}}$ & $66.00 \pm 0.89^{\mathrm{eA}}$ \\
\hline 48 & $28.28 \pm 6.62^{\mathrm{bB}}$ & $22.45 \pm 3.10^{\mathrm{aA}}$ & $73.00 \pm 2.00^{\mathrm{bB}}$ & $20.00 \pm 0.52^{\mathrm{cA}}$ \\
\hline 72 & $29.31 \pm 9.57^{\mathrm{bB}}$ & $23.14 \pm 3.36^{\mathrm{abA}}$ & $72.00 \pm 1.79^{\mathrm{bB}}$ & $17.00 \pm 0.63^{\mathrm{bA}}$ \\
\hline 96 & $21.77 \pm 2.64^{\mathrm{aA}}$ & $21.08 \pm 1.83^{\mathrm{aA}}$ & $59.00 \pm 1.41^{\mathrm{aB}}$ & $8.00 \pm 1.41^{\mathrm{aA}}$ \\
\hline 120 & $27.25 \pm 8.14^{\mathrm{bA}}$ & $25.54 \pm 3.10^{\mathrm{bA}}$ & $90.00 \pm 2.61^{\mathrm{dB}}$ & $39.00 \pm 1.41^{\mathrm{dA}}$ \\
\hline
\end{tabular}

* Mean \pm standard deviation; the lower is the value, the higher is the antifungal activity. The same small letters in the same column are not significant different by Tukey test $(\mathrm{P}>0.05)$, when different incubation times for intention of yeast supernatant are compared. The same capital letters in the same line are not significant different by Tukey test $(\mathrm{P}>0.05)$, when treatment yeast supernatant is compared with control (fungal growth without yeast supernatant). 
In the assay carried out against $P$. expansum, there was a significant difference $(\mathrm{p}<0.05)$ between the control and the treatment with the cell-free culture supernatant after 24-120h; spore germination inhibition was not very efficient when the cell-free culture supernatant was used after $24 \mathrm{~h}(13.85 \%$ inhibition), increasing considerably with the cellfree culture supernatant after 48-72h (50-53.2\%), and reaching the maximum inhibition level after $96 \mathrm{~h}$ incubation $(93.33 \%$ spore germination inhibition). After $120 \mathrm{~h}$ incubation time, antifungal activity slightly decreased to $76.62 \%$ inhibition level (Fig. 2C). As for hyphal growth inhibition, there was a significant difference $(\mathrm{p}<0.05)$ between the cell-free culture supernatant treatment after $72-120 \mathrm{~h}$ and the control treatment, showing the highest hyphal growth inhibition after 96h incubation time $(28.45 \%$, Fig. 2A). These results suggested that the use of cell-free culture supernatant from Kluyveromyces sp. FP4 13 cultivate during $96 \mathrm{~h}$ could efficiently control the hyphal growth and conidial germination of $P$. expansum.

Tests conducted against the hyphal growth of $A$. ochraceus showed a significant difference ( $\mathrm{p}<$ 0.05 ) between the treatment and the control of the yeast cultivate after 48-72 h (Table 4). However, inhibition percentage was not higher than $21 \%$ (Fig. 2B). The conidial germination results were similar to that found against $P$. expansum, i.e., there was a significant difference between the treatment and the control of the yeast cultivated for $24 \mathrm{~h}(16.5 \%$ inhibition level), increasing after 48-72h (inhibition of 72.6-76.39\%), and reaching maximum activity after $96 \mathrm{~h}$ incubation (inhibition of $86.44 \%$ ). After $120 \mathrm{~h}$, antifungal activity was drastically reduced to $56.7 \%$ (Fig. 2D). Thus, based on the results, the use of cell-free culture from yeast cultivate at $25^{\circ} \mathrm{C}$ for $96 \mathrm{~h}$ could efficiently control spore germination of A. ochraceus.
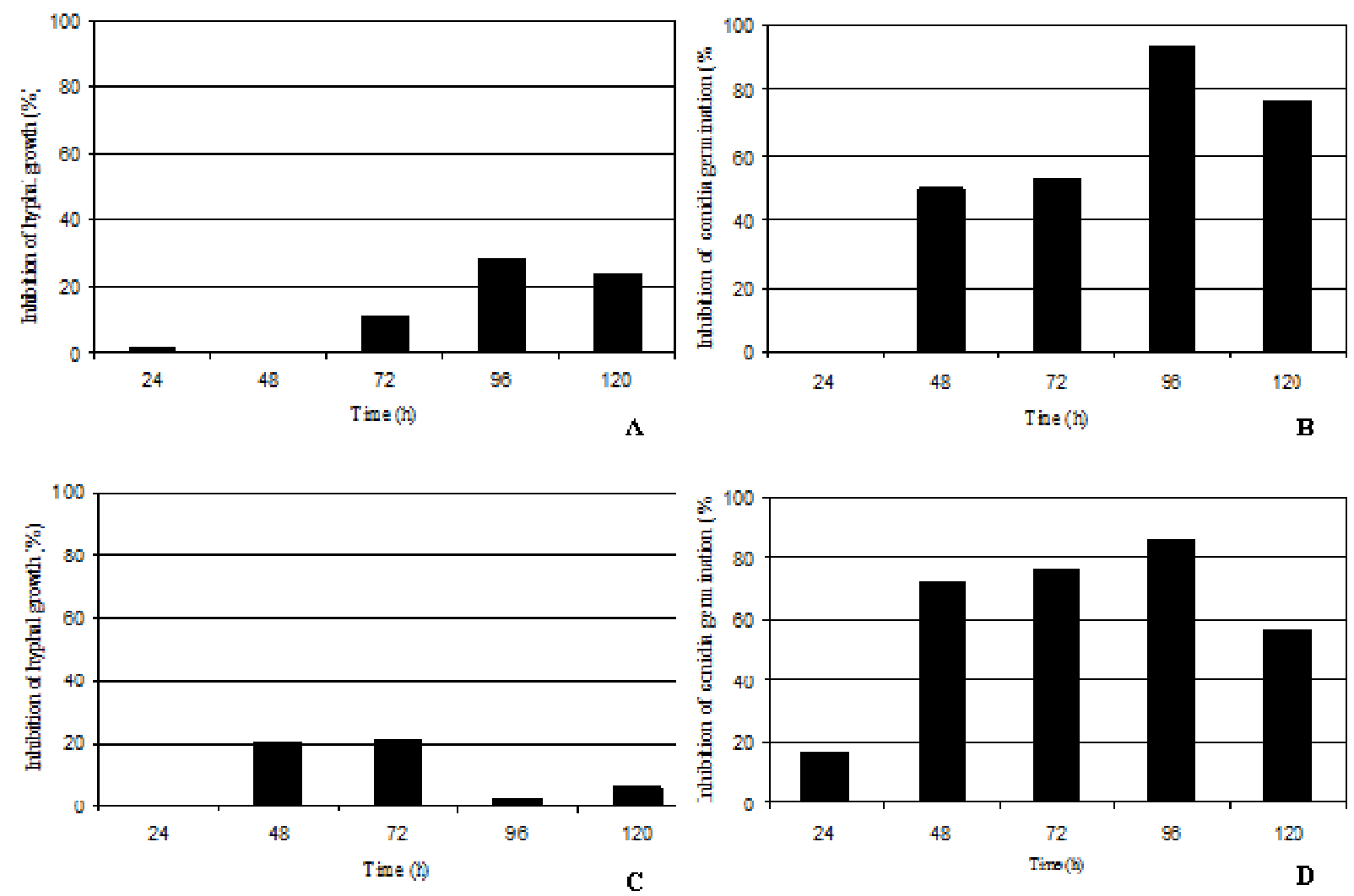

Figure 2 - Inhibitory activity against Penicillium expansum n. 2 and Aspergillus ochraceus A152 by cell-free culture supernatant from Kluyveromyces sp. FP4 $4_{13}$ cultivate. A, C: Inhibition percentage of hyphal growth; B, D: Inhibition percentage of conidia germination. The higher is the value, the higher is the inhibition percentage. 
In the YM broth assay, antifungal activity was evidenced as the presence of an extra-cellular substance that could efficiently inhibit spore germination of both the filamentous fungi. The antagonism of Kluyveromyces sp. FP $4_{13}$ against $P$. expansum and $A$. ochraceus based on the antibiosis suggested the involvement of such factor with killer positive phenomenon shown in this work. As the killer toxin was capable of inhibiting the conidial germination and hyphal growth, the effect was probably associated with rapid loss of cellular integrity rather than inhibition of the cell division cycle. Mechanisms associated with the cell surface have been reported in $S$. cerevisiae $\mathrm{K} 1$ toxin, which was linked to cell wall receptor (De La Peña et al. 1981), such as in Pichia membranifaciens killer toxin (Santos and Marquina 2004). Walker et al. (1995) reported the susceptibility of yeast and filamentous fungi caused by the killer positive strains of $S$. cerevisiae, $P$. anomala and Williopsis mrakii. Studies by Coelho et al. $(2006,2007)$ showed $58.15 \%$ inhibition of spore germination of $P$. expansum with supernatant of $C$. guilliermondii cultivate obtained after $72 \mathrm{~h}$ of incubation at $25^{\circ} \mathrm{C}$, whereas Pichia ohmeri $\left(25^{\circ} \mathrm{C} / 48 \mathrm{~h}\right)$ inhibited the hyphal length development in $64.37 \%$, both associated with the killer factor.

Although there had not been any reports on the action of killer toxins produced by Kluyveromyces sp. against molds, Comitini et. al (2004) reported the fungicidal effect of Kwkt killer toxin by $K$. wickerhamii (DBVPG 6077) against Dekkera/Brettanomyces spp. spoilage yeasts in wine and concluded that this killer toxin could have great potential as a bio-preservative agent in wine ageing.

\section{CONCLUSION}

Of the 41 yeasts tested, $75.6 \%$ showed killer phenomenon against at least one sensitive standard yeast used as reference, indicating a good number of yeasts producing extra-cellular substance. The antagonism showed by the yeasts tested against $P$. expansum and $A$. ochraceus based on the antibiosis rendered them promising biocontrol agents against the spoilage mould in postharvest fruit. The killer positive isolate $\mathrm{FP} 4_{13}$ of Kluyveromyces sp. significantly inhibited the conidial germination of $P$. expansum and
A. ochraceus, reaching about 93.33 and $86.44 \%$ inhibition, respectively. However, further studies on the antagonistic microorganisms with innocuous characters would be needed and purification and characterization of new killer toxins must be carried out to improve the quality and safety of agro-industrial products.

\section{ACKNOWLEDGEMENTS}

The authors would like to thank National Council of Scientific and Technological Development (CNPq, Brazil) for financial support.

\section{REFERENCES}

Castoria R, De Curtis F, Lima G, Caputo L, Pacifico S, De Cicco V. Aureobasidium pullulans (LS-30) an antagonist of postharvest pathogens of fruit: study on its modes of action. Postharvest Biol Tec. 2001; 22: 7-17.

Chen Z, Brown RL, Lax AR, Cleveland TE. Inhibition of plant-pathogenic fungi by a corn trypsin inhibitor overexpressed in Escherichia coli. Appl Environ Microb. 1999; 65(3): 1320-1324.

Coelho AR, Hoffmann FL, Hirooka EY. Biocontrole de doenças pós-colheita de frutas por leveduras: perspectivas de aplicação e segurança alimentar. Semina Ciênc Agrar. 2003; 24(2): 347-368.

Coelho AR, Levy RM, Hoffmann FL, Taniwaki MH, Kmelmmeier C, Pagnocca FC, et al. Potential biocontrol of patulin producing Penicillium expansum in postharvest fruits using antagonistic yeasts. In: Njapau H, Trujillo S, Van Egmond HP, Park DL, editor. Mycotoxins and Phycotoxins: advances in determination, toxicology and exposure management. Netherlands: Wageningen Academic Publishers; 2006. p. 249-257.

Coelho AR, Celli MG, Ono EYS, Wosiacki G, Hoffmann FL, Pagnocca FC, et al. Penicillium expansum versus antagonist yeasts with perspectives of application in biocontrol and patulin degradation. Braz Arch Biol Techn. 2007; 50: 725-733.

Coelho AR, Nóbrega GMA, Pagnocca FC, Hoffmann FL, Harada KI, Hirooka EY. Avaliação do potencial antagônico de leveduras, visando biocontrole de deterioração por Penicillium expansum. Semina Ciênc Agrar. 2011; 32: 1879-1892.

Comitini F, Ingeniis J, Pepe L, Mannazzu I, Ciani M. Pichia anomala and Kluyveromyces wickerhamii killer toxins as new tools against Dekkera/Brettanomyces spoilage yeasts. FEMS Microbiol Lett. 2004; 238: 235-240. 
De La Peña P, Barros F, Gascón S, Lazo PS, Ramos S. Effect of yeast killer toxin on sensitive cells of Saccharomyces cerevisiae. J Biol Chem. 1981; 256(20): 10420-10425.

Droby S, Vinokur V, Weiss B, Cohen L, Daus A, Goldschmidt EE et al. Introduction of resistance to Penicillium digitatum in grapefruit by the yeast biocontrol agent Candida oleophila. Biol Control. 2002; 92: 393-399.

Food Agriculture Organization - FAO. 2010 [Accessed in 2012 Jun 20]. Available from: http://faostat.fao.org/site/339/default.aspx.

Geng P, Chen S, Hu M, Rizwan-Ul-Haq M, Lai K, Qu $\mathrm{F}$, et al. Combination of Kluyveromyces marxianus and sodium bicarbonate for controlling green mold of citrus fruit. Int J Food Microbiol. 2011; 151: 190194.

Golubev WI. Mycocins (killer toxins). In: Kurtzman CP, Fell JW, editor. The yeasts, a taxonomic study. London, Academic Press. 1998. p. 55-62.

Hussein HS, Brasel JM. Toxicity, metabolism, and impact of mycotoxins on humans and animals. Toxicology. 2001; 167(2): 101-134.

Instituto Brasileiro de Frutas - IBRAF. Estatísticas de Frutas Frescas. 2010 [Accessed in 2012 Jun 20]. Available from: http://www.ibraf.org.br/estatisticas/est_frutas.asp.

Janisiewicz WJ, Korsten L. Biological control of postharvest diseases of fruits. Anпи Rev Phytopathol. 2002; 40: 411-441.

Janisiewicz WJ, Tworkoski TJ, Sharer C. Characterizing the mechanism of biological control of postharvest diseases on fruits with a simple method to study competition for nutrients. Phytopathology. 2000; 90(11): 1196-1200.

Janisiewicz WJ, Leverentz B, Conway WS, Saftner RA, Reed AN, Camp MJ. Control of bitter rot and blue mold of apples by integrating heat and antagonist treatments on MCP treated fruit stored under controlled atmosphere conditions. Postharvest Biol Tec. 2003; 29(2): 129-143.

Janisiewicz WJ, Conway W, Glenn M, Sams C. Integrating biological control and calcium treatment for controlling postharvest decay of apples. Hortscience. 1998; 33(1): 105-109.

Nielsen KF, Sumarah MW, Frisvad JC, Miller JD. Production of metabolites from the Penicillium roqueforti complex. J Agr Food Chem. 2006; 54(1): 3756-3763.
Oliveira AV, Rabelo PR, Portes CS, Coelho AR. Biocontrole in vitro de Botrytis cinerea por leveduras killer visando aplicação em morangos pós-colheita. RECEN. 2011; 13(3): 353-364.

Philliskirk G, Young TW. The occurrence of killer character in yeasts of various genera. A Van Leeuw. 1975; 41(2): 147-151.

Platania C, Restuccia C, Muccilli S, Cirvilleri G. Efficacy of killer yeasts in the biological control of Penicillium digitatum on Tarocco orange fruits (Citrus sinensis). Food Microbiol. 2012; 30: 219-225.

Polonelli L, Archibussi C, Sestito M, Morace G. Killer system: a simple method for differentiating Candida albicans strains. J Clin Microbiol. 1983; 17(5): 774780.

Rezende JAM. Fancelli MI. Doenças de mamoeiro. In: Kimati H, Amorim A, Bergamin Filho A B, Camargo LEA, Rezende JAM. editor. Manual de fitopatologia: doenças de plantas cultivadas. São Paulo: Agronômica Ceres. 1997. p. 261-297.

Santos A, Marquina D. Killer toxin of Pichia membranifaciens and its possible use as a biocontrol agent against grey mould disease of grapevine. Microbiology. 2004; 150(7): 2527-2534.

Schmitt MJ, Breinig F. The viral killer system in yeast: from the molecular biology to application. FEMS Microbiol Rev. 2002; 26: 257-276.

Walker G, Mcleod A, Hodgson V. Interactions between killer yeast and pathogenic fungi. FEMS Microbiol Lett. 1995; 127: 213-222.

Wilson CL, Wisniewski ME. Biological control of postharvest plant diseases of fruits and vegetables: theory and practice. Boca Raton: CRC Press. 1994. p. 465.

Wisniewski M, Wilson C, Droby ES. Postharvest Biocontrol: New Concepts and Applications. In: Vincent C, Goettel MS, Lazarovits G. editor. Postharvest Biocontrol: New Concepts and Applications. CABI, Cambridge, MA, USA. 2007. p. 262-273.

Received: October 10, 2012; Accepted: June 18, 2013 
